\title{
CRITICAL DISCOURSE ANALYSIS ON THE PROGRAM OF INDONESIANLAWYER CLUB ON TV ONE IN THE PERSPECTIVE OF NORMAN FAIRCLOUGH \\ ( Episode: Difficulty of The Execution of Jendral Susno Duaji)
}

\author{
Muhamad Mukhroji \\ A permanent lecturer of Islamic University of Balitar Blitar East java \\ Email:adjie_chadel@yahoo.com
}

\begin{abstract}
Abstrak. Artikel ini mereview sebuah wacana kritis penerapan perspektif Norman Fairclough sebagai dasar analisa. Ada 3 jenis dimensi analisa menurut Fairclough, yaitu struktur kalimat, lexicon, dan meaning. Artikel ini adalah laporan kecil pada sebuah riset CDA kecil melalui analisa pada acara 'talk show', klub pengacara Indonesia di stasiun TV one. Data berasal dari rekaman ujaran-ujaran dari para pembicara di acara tersebut, terdiri dari 9 bagian acara (host), pengacara, Susno Duaji, dan pengacaranya, dan ahli yang diundang. Riset ini mengimplementasikan wacana kritis khususnya berdasar pada Norman Fairclough untuk mengungkap meaning yang tersirat dari pembicara. Ditemukan bahwa ada dorongan memberikan pragmatis yang tersirat ditemukan di tiap rekaman yang memungkinkan penonton untuk mengerti maksud dari pembicara dengan mudah.
\end{abstract}

Kata kunci: $C D A$, makna tersirat, dorongan pragmatis, maksud pembicara

\begin{abstract}
This article reviews a criqlltical discourse analysis implementing Norman Fairclough perspective as the basis of analysis. There are three kinds of dimensions to analyze according to Fairclough, they are sentence structure, lexicon, and meaning. This article is a small report on a small CDA research by analyzing a television talk show, Indonesian Lawyer Club on TV One. The data are utterances recorded from the intercollutors in the event consisiting of nine parts of recording. They are Karni Ilyas, the host of the event, attorneys, Susno Duaji and his lawyer, and experts invited to the event. The research implemented critical discourse analysis especially based on Norman faiclough to uncover the implied meaning of the speaker. It was found that there were implicatures giving pragmatic force which were found in each recording which enabled watchers to understand the speaker meaning easily.
\end{abstract}

Keyword:. CDA, Implicature, pragmatic force, speaker meaning.

\section{INTRODUCTION}

It is agreed or disagreed that it seems very important to study discourse analysis more than the fact so far where recent teachers including English teachers still do not teach a material of discourse analysis to their students even they teach reading comprehension. In fact, there are still many English teachers in Junior or senior high schools teaching reading comprehension to their students using lexical and grammatical approach. Most of the teachers might have a little understanding about discourse analysis so that they teach their students vocabulary and grammar to understand the discourse or text.

Critical Discourse Analysis (CDA) mostly analyzes on the relationship between language and its context of its use. To understand a discourse, it is needed to pay attention to all the components involved in the usage of language. The involved components in this language use are called contexts. The contexts cover everything in language use. Brown and Yule (1983) used the term co-ordinate referring to the knowledge of world.Then, contexts arethe texts preceding or following a text. Therefore, analyzing a discourse is very 
beneficial in studying the meaning of the language in a real use.

In recent days, discourse has a broader reference. Recently, the term of discourse is used in social sciences and used to refer to public discussion such as to analyze mass media both printed and electronic media. However, experts in discourse especially in linguistics have already agreed that discourse is the biggest language unit and used in communication. The language unit under discourse is sentence, phrase, word, and phone. In succession a set of phone produces a word, a set of words produces a phrase, a set of phrases produces a sentence, and finally a set of sentences produces a text in the form of discourse.

Most analysts assume that there are an addressor and an addressee in discourse analysis. In spoken discourse, a speaker plays a role of addressor while a listener serves as an addressee. In written discourse, however,the addressor and the addressee do not communicate directly face to face. The addressorexpresses his/her ideas in the form of linguistic codes such as a set of sentences or text. The organized sentences then are interpreted by the readers (addressee). Here, the readers get the sense based on wellorganized words printed in the text relaying on the schemata or their background knowledge.

In oral communication (such as conversation), discourse can be considered as a process (Brown and Yule, 1983). Here, a discourse is a set of utterances spoken orally. In oral communication, interlocutors (participants of communication) in turn communicate one another.Conversation happens to a group of people gathering together, providing time to do communication one another until they end it.In doing so, those interlocutors have right and duty to listen or respondone anotherand try to reach the sense of the conversation among the interlocutors. When one of the interlocutors serves as a speaker, s/he can deliver information, invite, command, express a proposal and say a suggestion etc.
In turn, the listener has right and duty to listen, and take a role as a speaker to respond the previous talk.In oral communication, utterances are very much influenced by contexts. Since a spoken discourse is temporarily acted meaning that it is not traced unless it is recorded, the interpretation must involve the context when the utterances are spoken. It was said previously that discourse is a matter of language use in communication, both in spoken and written (Brown dan Yule; 1983). Language use can be in a form of advertisement, talk, discussion, debate, letters, thesis, etc. While Van Djik (1987) cites that discourse is the abstract theoretical construct. Therefore, discourse according to Van Djik cannot be seen as a language existence because a discourse existence is a text. According to Halliday dan Hasan (1985:10) though a text consists of a series of meanings, a text is basically consisting of a meaning unit. Since a text is a meaning unit, a text must be seen from two points of view, both as a product and as a process.

\section{According to Coulhard (1981:6),} there are at least four components of linguistics in a language analysis especially spoken language, there are; phonology consisting of phoneme, syllables, and a group of phones, then structure consisting of morpheme, words, phrases, clauses and sentences, next discourse covering act, move, exchange, and transaction, finally, nonlinguistic covering stage and transaction.Implicitly, here Couldhard has limited the scope of discourse on act, move, exchange and transaction. On the other hand the reference cited by Coulhard seems to be too large in scope because the analysis covers both linguistics and non-linguistics. According to discourse analysis experts (Brown and Yule, 1983), the point of discourse is a language use which can be in a form of sentence to communicate in social context. As stated previously, a science which studies on the real language use in communication act is discourse analysis. Stubbs (1983:1) cites that discourse analysis 
is an analysis which studies language use naturally, either in the form of written or spoken. The natural language use refers to the language use in daily communication. Stubbs explains that discourse analysis emphasizes on the study on language use in social context, especially in interaction among interlocutors.

To analyze the data, the researcher uses the critical discourse analysis approach in the perspective of Norman Fairclough having the characteristic of social cognitive showing three dimensions of analysis on text, there are; text dimension, discourse practice dimension, and social culture practice dimension. The researcher limits his study on discourse practice dimension because of limited time to discuss. To specify the research focus, he analyzes the discourse practice dimension where the analysis will focus on the process of text production by speaker, listener, media, and communication process or interpretation by public.

Furthermore, the analysis represents the discourse, implicature and pragmatic force focusing on the way how the text is represented, whether it is direct or indirect. The analysis of implicature and pragmatic force are done towards conversation text in order to analyze the sense meant by the speaker based on the context; when, where, by whom, and to whom the utterance is uttered. Although some utterances are semantically having similar meaning, the implicature and pragmatic force of the utterances differ significantly depending on the context. The reason why the researcher limits his study on this is that the time to present is limited, however, the discussion is expectedly broad and sufficient for understanding the point of discourse.

The typical characteristic of critical discourse analysis by Norman Fairclough is that the subject analyzed covers three main things which cannot be separated one another. They are language structure, diction, and meaning. The language structure will be analyzed part because the sentences with certain structure gives certain message too. It means that it has certain sense too. The diction used by the speaker also gives special sense as prior ideology. Moreover, meaning is also an important thing in the analysis according to Fairclough based on the provided context. Based on the background above, the general problem being discussed in this article is "How language use applied in the dialogue of Indonesian Lawyer Club can give ideology and power of the speaker?"

Derived from the general problem, the research problem is then developed into three sub problems; they are:

a. How is sentence structure used in the dialogue of ILC?

b. How is the diction chosen to convey the message in the dialogue of ILC?

c. How is implied meaning spoken by speakers in the dialogue of ILC?

This research is aimed at giving a theoretical understanding about critical discourse analysis and its implication in teaching English especially in teaching reading and speaking. Furthermore, it is also aimed at giving more opportunities to students or lecturers to conduct research in the field of critical discourse analysis.

\section{Theoretical review.}

Critical discourse analysis (CDA)is a discourse analysis used in society implementing critical approach. Historically, CDA has relationship with the idea of Halliday (1985:36) about instrument linguistic. The instrument Linguistic is an analysis of language to understand the world especially about social system through language analysis.As a discourse analysis, CDA also utilizes the concepts cited by linguists and experts of discourse analysis using descriptive approach.

Critical Discourse Analysis such as discourse analysis also analyzes discourse containing language use as an information conveyor so that it enables society develop their culture, law, ideology, religion, and custom. According to Brown and Yule (1983:1-2) the language function used as a transfer of information is called transactional function.Moreover, they also state that 
discourse also has interactional function. Analysts on spoken text or conversation emphasize more on the language use to get agreed role, sense of solidarity among friends, speech exchange, and saving of face etc. Such kind of interactional function seems to be a daily communication.

CDA can be considered as an analysis method towards the language use using critical approach. Critical approach is usually contrasted to descriptive and positivism approach. The critical approach has a historical relationship with critical philosophy developed by European philosopher. The critical philosopher was Marxist philosophy which didn't follow philosophy principles developed by Karl Marx. However, critical philosophy took much inspiration from Karl Mark's intellectual creation. The typical characteristic of critical philosopher is that it always relates to critics towards factual social relationship.

According to $\mathrm{CDA}$, language is managed and produced bystatements having objectives. Every statement is an action to create sense. In short, sense or meaning is expressed by discourse. In this case discourse becomes a means to express implied meaning. Therefore, CDA can be used as a means to uncover the intended meaning.

CDA can be used to analyze how a discourse is produced and reproduced. The involved sender of the message in the discourse production cannot be considered as a neutral subject. The topics or objects are chosen based on careful consideration. In advertisement discourse, the conveyed messages are seemly not neutral, but they have been chosen and considered to be able to influence others (customers) to act. Meanwhile, the message receivers can interpret freely a discourse based on their own thought and the social power in their community. They have their own background knowledge and schemata to create their own context.

Fairclough (1998)argues that critical linguistics analyzes language and relates it with ideology. The term of ideology in CDA is not similar to that in politics. The reference of ideology in CDA is broader than that in politics. The ideology in this context can refer to the intention which is achieved using discourse and can cover the mindset and behavior used in politic world. Then, according to critical linguistics analysis, the language including language structure used in language use takes us to a certain position and shows a certain ideology. In other words, the position of information source (producer) and his/her ideology can be observed by analyzing the language used.

The approach of CDA by Fairclough emphasizes that there is a significant relationship between ideology aspect and power. The ideology is used to get the power and the power tends to create power practice. A text is considered to have ideology (ideological text) in case the text contains a struggle for hegemony achieved in a text. Fairclough furthermore assumes that ideological text is a text which shows inequality and unfairness.

\section{METHOD}

Relating to the research problems and analysis field, the discourse analysis on this ILC program is using critical discourse analysis approach. This approach has suitable characteristics to conduct this research, in addition, the critical discourse analysis approach can be used to uncover everything expressed implicitly especially related to ideology meaning in the dialogue at the program of ILC.

This small research used qualitative research design purposed by Bogdan dan Biklen (1982 :27-30) where the qualitative design has characteristics as follow; (a) using natural background as direct data source, (b) the researcher plays as a prime instrument, (c) descriptive, (d) emphasizes on the process instead of the result, (e) inductive, (f) meaning becomes the priority in the analyze.

Basically, all the research data are utterances or conversation found in the dialogue of ILC where the participants of the dialogue were lawyers, politicians, and 
experts in law. The program of ILC was broadcasted by TV One broadcasting the program every Tuesdayfor about three hours including the advertisement breaks from $07.30 \mathrm{pm}$ until $10.30 \mathrm{pm}$. This data were taken from the program of ILC on May 30, 2013.

The type of the data is spoken text and expression move (gestures) and it is primary data.Transcripts were made based on the audio text derived from the original utterances broadcasted lively by TV One. While gestures and expression by the participants of dialogue were used as supporting data to give interpretation based on the context. The data sources were taken from the participants of the program of ILC consisting of three groups; the group of Susno Duaji, the group of executors, and the group of experts in law.

The data were analyzed to interpret the spoken discourse ideologically. The word of interpretation is used to uncover the intended meaning of the utterances in the dialogue. It was meant to reach the appropriate sense by using the context involved instead of lexical meaning only. Based on the research objectives, the research analysis was using critical discourse analysis. There are three levels of data analysis in this critical study; they are descriptive, interpretation, and explanation.

\section{DISCUSSION}

In this discussion, the researcher will discuss about the analyzed data based on the problems in this research. The discussion will uncover the following problems; they are: (a) How is sentence structure used in the dialogue of ILC?, (b) How is the diction chosen to convey the message in the dialogue of ILC?and (c) How is implied meaning spoken by speakers in the dialogue of ILC?.Due to the time of presentation and the limit of pages to write, the researcher would like to analyze two samples of discourse (Karni Ilyas' utterances and Susno Duaji's utterances out of nine discourses he recorded).
To shorten the discussion of those three problems, the researcher will elaborate in one integrated discussion describing the sentence construction, the diction, and the intended meaning (implied meaning). In discussing sentence structure, it is always related to sentence forms which are classified based on the sense. According to Speech Act analysis by Searle,1975), the utterances used in the dialogue are as follows:

Data 1 (Karni Ilyas, the host)

"Malam ini saya tidak punya pilihan lain kecuali mengangkat judul "Susahnya mengeksekusi Jendral Susno". Seperti yang diberitakan oleh media bahwa Komisaris Jendral (purnawirawan) Susno Duaji akan dieksekusi dirumahnya di Perumahan Dago Bandung. Yang menarik adalah dia gagal dieksekusi oleh kejaksaan. Dan yang lebih menarik adalah kepolisian setempat yaitu polda Bandung menghalangi atau dengan istilah yang tepat adalah "mengamankan" Susno Duaji dari eksekusi kejaksaan (sambil menunjukan jarinya mengisyaratkan tanda petik). Ini menarik karena kejaksaan adalah institusi pemerintah yang bertugas berdasarkan undangundang, sementara kepolisisan juga lembaga abdi negara yang bertugas atas dasar konstitusi atau undangundang juga. Kedua institusi ini sekarang dalam persimpangan terkait eksekusi Jendral Susno. Jendral Susno berargumen bahwa surat MA yang diputuskan cacat demi hukum karena dalam amar putusan tidak ada diktum yang menyatakan Susno Duaji harus ditahan".

Data II (Susno Duaji's statement)

"Sebagaimana yang diberitakan bahwa saya dianggap status buron oleh kejaksaan. Ini satu bukti bahwa ada kesalahan dalam masalah saya dan ini sudah cukup untuk menuntut kejaksaan dengan tuduhan melanggar pasal 333 KUHP. Setidaknya ada tiga bukti saya cukup menangkap 
kejaksaan, pertama surat eksekusi yang salah dan datang kerumah saya di Dago dengan paksa, kedua mengeluarkan surat bahwa saya sebagai buron, dan ketiga mengeluarkan surat pencekalan. Ini bukan delik pengaduan tetapi sebuah delik biasa. Sekarang berani gak polisi berbuat".

"Saya ada data perlakuan yang berbeda antara saya dengan orang lain seperti Fahrudin tersangka korupsi bank Mandiri 60 milyar hingga kini tidak dieksekusi dan masih banyak nama-nama lainnya yang tidak diproses oleh kejaksaan. Saya sangat apresiasi kepada institusi polisi dengan harapan kepolisian memiliki integritas tinggi serta profesionalisme yang kuat dan tidak terpengaruh oleh intervensi luar".

In the above utterances there are many sentences containing ideology called ideological text such as passive utterances where the speaker didn't want their utterances sounded explicit. The clause like "...bahwa Komisaris Jendral (purnawirawan) Susno Duaji akan dieksekusi dirumahnya di Perumahan Dago Bandung". The clause has a meaning that the speaker, Karni Ilyas, did not want that the executors were mentioned as the actors of the execution. It was done to avoid the message that there was a problem between two big government institutions (Police Department and prosecutor Department). The ideology owned by Karni Ilyas is used to give the smooth impression that the enmity between the two institutions does not look too brisk.

Furthermore, the diction chosen also has a specific purpose or ideology in order that the utterances in the dialogue give a cool impression or it is aimed to muffle the enmity. The choice of the word "mengamankan" impresses a politeness of expression or even produces an ideology to cool the critical condition between the two disputing institutions. Actually the speaker could use the word "melarang eksekusi" to make the utterance clearer or more explicit and even it can impress provoke the listeners, however, the speaker has a different ideology to make his utterance sound cool and finally it can make the condition better.

The utterances above contain implicit meaning although there were some explicit meaning found in those utterances. The utterance like "...polda Bandung menghalangi atau dengan istilah yang tepat adalah"mengamankan" Susno Duaji dari eksekusi kejaksaan (showing his point fingers indicating 'quote and quote') has implicit meaning that it seemed clumsy because Susno Duaji, who was the General of Police, even broke the law by refusing to be executed and it even had an impression that he was protected by his corps. It was contrary to the fact that police should help enforce the law by executing the accused Susno Duaji not to protect him. The diction used that is "mengamankan" might have explicit meaning that is giving the safety from the danger.However, in this context the word "mengamankan" was used to give a more implicit meaning that is giving the protection of law to Susno Duaji who was a general of police at that time so he was expected no to be executed. The gesture of the speaker showing his fingers of quote gave a more impression not to utter explicitly.

Furthermore, discourse dimension containing implicature gave a pragmatic force so that the utterances which Karni Ilyas used gave a sense that Susno Duaji, a policeman, broke the law by objecting to being executed by the executors. However, the word "...mengamankan" gave an impression a more polite expression although it was such a law breaking. The diction "mengamankan" was chosen by the speaker to make the expression more polite although it seemed to protect the accused from the broken law where he should not have committed it.

While the social and culture dimension covered the context following the dialogue. As the collected data, there were many words which were not interpreted 
lexically because they were followed by the context. Therefore, the utterances should be interpreted deeply using the context following the dialogue. In the utterance "Ini bukan delik pengaduan tetapi sebuah delik biasa. Sekarang berani gak polisi berbuat'has an implicit meaning as a command utterance stated by Susno Duaji who was a general of police having a strong influence or power to make an order (command). In micro analysis, the utterance has situational analysis describing emotion or feeling of interlocutors who have such problems.In the utterance "Ini bukan delik pengaduan tetapi sebuah delik biasa" looked an affirmative sentence but it gives a sense of a command to the corps of police to do an action of executing the speaker (Susno Duaji) by seizing the executors because to him it was breaking the law chapter 333. The other utterance"Sekarang berani gak polisi berbuat"seemed a question sentence but it has a command because it was spoken emotionally by Susno who experienced the problem. To fulfill the felicity condition, the context should follow the utterances. The speaker should be the one who has the authority to give an order and Susno Duaji has completed the requirement of felicity condition because he was a general of police as a former the head of crime affairs in the police department.

\section{Conclusion}

The conclusion will be elaborated briefly based on the result of finding in this small research as the answers of the research problems where Fairclough analysis is limited on the text analysisconsisting of sentence structure, diction, and meaning using the approach of text dimension, discourse, and social culture dimension.

a. The utterance used by speakers in the dialogue in ILC were active sentences, passive, and indirect sentences which have pragmatic force and they are interpreted based on the ideology and power of the speakers. The utterances used in ILC mostly gave implicature and were understood by using the context to reach the proper sense.

b. The diction used is chosen specially to give ideology and power of the speaker. Moreover the lexicon which the speaker used has implied meaningto make his/her utterances more polite.

c. The implied meaning of the utterances depends very much on the context of the speaker, the objects uttered, and the topics of utterances. In short words, meaning is more influenced by language, ideology, and power of the speaker.

d. It is important for the English teachers teach the theory of discourse analysis in practice especially when they teach reading comprehension.

\section{REFERENCES}

Austin, J.L. 1962. How to do thing with words. Cambridge: Cambridge University Press.

Bogdan, Robert C and S. Knopp Biklen. 1998. Qualitative Research for Education. An

Introduction to Theory and Method. New York: A Viacom Company.

British Council. 1997. The Future of English: A Guide to Forecasting the Popularity of the English Language in the 21th Century. London: British Council.

Brown, Gillian \& George Yule. 1983. Discourse Analysis. Cambridge: Cambridge University

Celce-Murcia, M., and Olshtain, E. 2000. Discourse and Context in Language Teaching. A Guide for Language Teaching. Cambridge: Cambridge University Press.

Cutting, Joan.2008. Pragmatic and Discourse. Routlege 270 Madison Ave,New York,NY 10016.2008

Eriyanto. 2001. Analisis Wacana: Pengantar Analisis Tesks Media. Yogyakarta: PT LkiS Pelangi Aksara. 
Fairclough,Norman.1989. Language and Power. Longman Group UK. London. 1989.

Fairlough, N. 1995. Critical Discourse Analysis: The Critical Study of Language. Singapore: Longman Singapore Publisher (Pte) Ltd.

Geis, M.L. 1982. The Language of Television Advertising. New York: The Academic Press.

Glasser, B., \& Strauss, A. 1967. Discovery of Grounded Theory: Strategies for Qualitative

Research. New York: Aldine Publishing Company.

Grice, H.Paul. 1975. Logic and Conversation dalam Davis S; Pragmatics: A Reader. New York: Oxford University Press

Miles, M.B., and Huberman, A.M. 1984. Qualitative Data Analysis, 16. Newbury Park: CA, Sage.

Patton, M.Q. 1994. Qualitative Evaluation and Research Methods, $2^{\text {nd }} E d$. Newbury Park: CA, Sage.

Rustono. 1998. Implikatur Percakapan sebagai Pengungkapan Humor di dalam Wacana

Humor Verbal Lisan Berbahasa Indonesia. Jakarta: Universitas Indonesia
Sides, CH. 1999. How to Write \& Present Technical Information. Phoenix, Arizona: The Oryx Press.

Sobur, Alex. 2006. Analisis Teks Media. Bandung: PT. Remaja Rosdakarya.

Stubbs, M. 1983. Discourse Analysis: The Sociolinguistics Analysis of Natural Language. Chicago: The University of Chicago Press.

Sujito. 2007. Penafsiran Wacana Iklan Berdasarkan Analisis Ko-teks. CERTEL, Jurnal Pendidikan Bahasa, 3(2):190-196.

Tracy, Karen. 1995. Action-Implicative Discourse Analysis, Journal Language and Social Psychology, 14:195215.http://comm.colorado.edu/tracy/re vised\%20LSI\%20handbook.htm. 03 August 2006.

Wijana, Dewa Putu. 1996. Dasar-Dasar Pragmatik. Yogyakarta: Andi Yogyakarta.

Wijayanti, F. 2007. Flouting Maxims in Durable Goods Advertisements in the Time Magazine. Unpublished Graduate Thesis. Malang: State University of Malang. 